\title{
CAPTURE IMMUNOASSAY FOR LT DETECTION PRODUCED BY ENTEROTOXIGENIC ESCHERICHIA COLI IN BACTERIAL ISOLATES
}

\author{
Caroline Anunciação Menezes ${ }^{1,2}$; Danielle Silva Gonçalves ${ }^{1}$; Jackeline Amianti'; ${ }^{1}$ Irene Fernandes ${ }^{3}$; \\ Carla Romano Taddei ${ }^{4}$; Paula Célia Mariko Koga ${ }^{1,2}$; Luiz Rachid Trabulsi' ${ }^{1}$; Marina Baquerizo Martinez ${ }^{4}$; \\ Roxane Maria Fontes Piazza ${ }^{\text {* }}$
}

\begin{abstract}
${ }^{1}$ Laboratório Especial de Microbiologia, Instituto Butantan, São Paulo, SP, Brasil. ${ }^{2}$ Fleury - Centro de Medicina Diagnóstica, São Paulo, SP, Brasil. ${ }^{3}$ Laboratório de Imunopatologia, Instituto Butantan, São Paulo, SP, Brasil. ${ }^{4}$ Departamento de Análises Clínicas e Toxicológicas, Faculdade de Ciências Farmacêuticas, Universidade de São Paulo, São Paulo, SP, Brasil.
\end{abstract}

This paper corresponds to an "extended abstract" selected for oral presentation in the $22^{\text {nd }}$ Brazilian Congress of Microbiology, held in Florianópolis, SC, Brazil, in November 17-20, 2003

\begin{abstract}
A capture enzyme-linked immunosorbent assay (ELISA), which detects LT-I toxin produced by enterotoxigenic Escherichia coli strains, has been developed. This capture assay was performed using the IgG enriched fraction of anti-LT-I antiserum and IgG2b anti-LT-I monoclonal antibody and allowed a clear distinction between E. coli LT-I - producing and non-producing strains. The estimated accuracy of the assay is $78 \%$ for sensitivity, $94 \%$ for specificity and $92 \%$ for efficiency. Thus, the capture immunoassay is a sensitive tool for detection of E. coli, which produces heat-labile enterotoxin, and is suitable for use in clinical laboratories and epidemiological surveys in developing world.
\end{abstract}

Key words: detection, polyclonal antibody, monoclonal antibody, thermo-labile toxin, E. coli.

\section{INTRODUCTION}

Enterotoxigenic Escherichia coli (ETEC) is a common cause of infectious diarrhea, especially in tropical climates, where uncontaminated water is not readily available. ETEC strains are an important cause of diarrhea among children in developing countries and are estimated to cause 700,000 deaths annually. ETEC are furthermore the main cause of traveler's diarrhea and, in Brazil, these pathogens are responsible for 7 to $20 \%$ of cases of infantile diarrhea $(1,2,6)$. The ability of these strains to colonize the small intestine is mediated by appendages called colonization factors ( $\mathrm{CFs})$. In addition, the most important characteristic of them is the production of heatlabile enterotoxin (LT) and/or heat-stable enterotoxin (ST), which are responsible for the intestine's fluids loss. For detection of the LT of enterotoxigenic E. coli, various assays methods have been developed, namely, GM1 - ELISA, modified Elek test, staphylococcal agglutination test and RPLA (5). However, some of these assay methods are unsuitable for routine diagnosis. Molecular methods have been used to detect LT genes, however, they cannot demonstrate toxin production. Thus, the aim of this study was the development of a capture assay method using a polyclonal rabbit and a monoclonal mouse IgG2b anti LT antibodies (Mabs) for detection ETEC LT producing strains.

\section{MATERIALS AND METHODS}

\section{Bacterial strains and culture conditions}

All E. coli strains used in this study were isolated from stools of children with and without diarrhea from sporadic cases in Brazil $(1,7)$. All bacterial strains were grown in LB broth at

*Corresponding author. Mailing address: Laboratório Especial de Microbiologia, Instituto Butantan, Av. Vital Brazil, 1500. 05503-900, São Paulo, SP, Brasil. Tel.: (+5511) 3726-7222. E-mail: roxane@butantan.gov.br 
$37^{\circ} \mathrm{C}$ for $18 \mathrm{~h}$ under constant shaking (200 rpm). The bacterial growth was centrifuged at $5000 \mathrm{Xg}$ and the supernatant was filtered through a $0.45 \mathrm{~mm}$ membrane. These conditions were employed in all experiments.

\section{LT antiserum}

Rabbits were immunized subcutaneously with $100 \mu \mathrm{g}$ LT (Sigma Chemical Co. St. Louis, MA, USA) in complete Freund's adjuvant and the IgG-enriched fractions were obtained from rabbit antisera after being submitted to caprylic acid and ammonium sulfate precipitation (4).

\section{IgG2b monoclonal antibody}

MAbs were produced as described by Köhler and Milstein (3) with some modifications. Popliteal lymphnode cells from $\mathrm{BALB} / \mathrm{c}$ mice immunized with $2 \mu \mathrm{g}$ of LT in complete Freund's adjuvant were fused with SP2-O cells (2:1) using polyethyleneglycol 4000 (Sigma Chemical Co. St. Louis, MA, USA). Hybrids were selected in HAT-RPMI 1640 medium (Sigma Chemical Co. St. Louis, MA, USA) containing 10\% FCS (Cultilab, Campinas, SP, BR).

\section{LT GM1 ELISA}

Microtiter plates (C96 Maxisorp - NUNC) were incubated at $37^{\circ} \mathrm{C}$ for $16 \mathrm{~h}$ with $1.25 \mu \mathrm{g} / \mathrm{mL}$ ganglioside GM1 in phosphatebuffered saline, pH 7.2 (PBS). And reaction was developed according to Svennerholm and Holmgren (8).

\section{Capture ELISA immunoassay}

Microtiter plates (C96 Polysorp - NUNC) were incubated at $4^{\circ} \mathrm{C}$ for $16 \mathrm{~h}$ with $25 \mu \mathrm{g} / \mathrm{mL}$ of anti-rabbit LT IgG enriched fraction in carbonate-bicarbonate-buffered, $\mathrm{pH}$ 9.6. Supernatant of bacterial cultures were incubated for 1 hour at room temperature. Unbound toxin was removed by washing them three times with PBS. Toxin bound to IgG enriched fraction was then detected with $2 \mu \mathrm{g} / \mathrm{mL}$ of $\mathrm{IgG} 2 \mathrm{~b}$ monoclonal antibody followed by anti-mouse $\mathrm{IgG}$ peroxidase (Zymed, 1:10,000). All experiments were carried out in quadruplicate and results correspond to three independent experiments. Differences were considered significant when the probability of equality was less than $0.05(\mathrm{p}<0.05)$.

\section{RESULTS AND DISCUSSION}

Expression of LT toxin can be used as a practical way to detect enterotoxigenic $E$. coli. Thus detection of toxin using phenotypic methods is more accurate and allows to incriminate the real pathogen responsible for diarrheal. Based up on this facts we obtained a polyclonal rabbit and a mouse monoclonal $\mathrm{IgG} 2 \mathrm{~b}$ anti-LT antibodies for standardization of a capture assay. The capture assay was performed using E. coli strains, from which virulence factors were previously determined by molecular methods. Capture assay statistical analysis suggests that the difference between the LT producing and non-producing strains by mean and standard deviation were considered extremely significant $(p<0.0001)$ (Fig. 1). The found values are $78 \%$ of sensitivity, $94 \%$ of specificity and $92 \%$ of efficiency. The capture assay was 3 fold more sensitive than GM1 ELISA. Thus this capture assay showed to be an excellent tool for LT producing strains detection and could be employed in the diagnosis of diarrhea caused by LT.

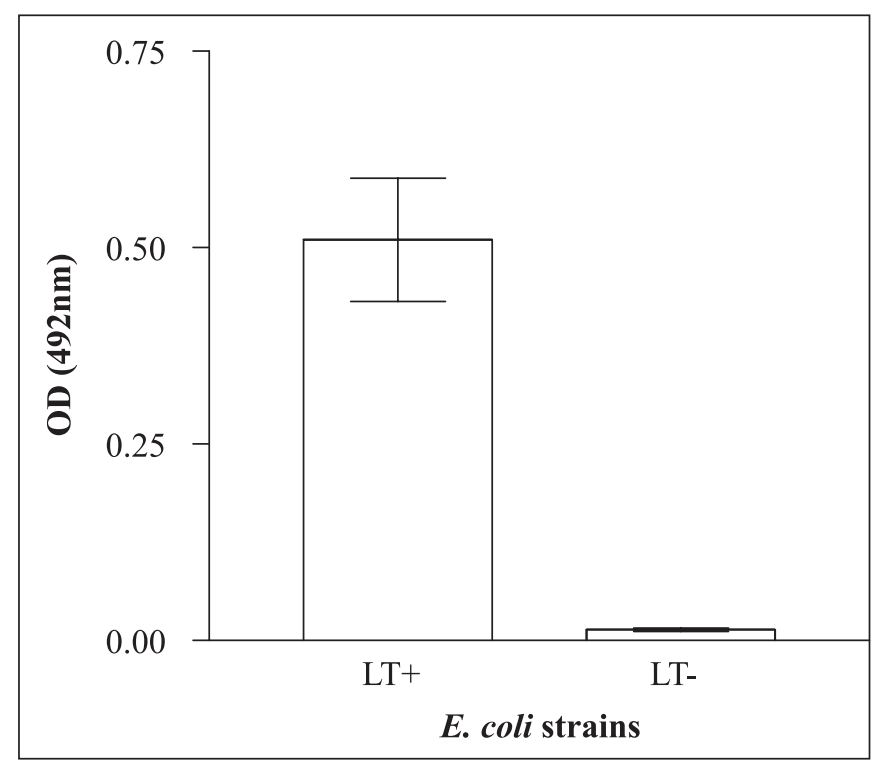

Figure 1. Distribution of LT producing and non-producing strains by capture assay. The reaction was detected with IgG enriched fraction of rabbit polyclonal and $\operatorname{IgG} 2 \mathrm{~b}$ monoclonal anti-LT. Goat anti-mouse IgG peroxidase labeled $(1: 10,000)$ and freshly prepared solution of OPD plus $\mathrm{H}_{2} \mathrm{O}_{2}$ recording of the $A_{492}$ on a Multiskan EX ELISA reader. Bars represent $95 \%$ confidence interval.

\section{ACKNOWLEDGMENTS}

This work was supported by FAPESP (grant 99/09458-0 to R.M.F.P., and fellowship to C.A.M).

\section{RESUMO}

\section{Imunoensaio de captura para detecção da toxina LT produzida por Escherichia coli enterotoxigênica em isolados bacterianos}

O objetivo do presente trabalho foi a padronização de um imunoensaio de captura para deteç̧ão de amostras de E. coli produtoras da toxina LT-I. Este ensaio de captura foi desenvolvido utilizando-se a fração enriquecida em $\operatorname{IgG}$ do 
anticorpo policlonal anti-LT e um anticorpo monoclonal caracterizado como IgG2b. Através deste método verificou-se uma clara distinção entre cepas de $E$. coli produtoras e não produtoras da toxina $(\mathrm{p}<0,0001)$, sendo a sensibilidade do método de $78 \%$, a especificidade de $94 \%$ e a eficiência de $92 \%$. Assim, o imunoensaio de captura mostrou-se como uma ferramenta sensível para a detecção de amostras de $E$. coli que produzem a enterotoxina termo-lábil, podendo ser aplicado em laboratórios clínicos e inquéritos epidemiológicos em paises em desenvolvimento.

Palavras-chave: detecção, anticorpo policlonal, anticorpo monoclonal, toxina termo-lábil, E. coli.

\section{REFERENCES}

1. Fernandes-Filho, A.; Montemor, L.P.G.; Gomes, T.A.T.; Santos Filho, L.; Trabulsi, L.R.; Martinez, M.B. Enteropathogens associated with acute diarrheal disease in urban infants in João Pessoa, Brazil. ASM $103^{\text {rd }}$ General Meeting, Washington, D.C. pp. 139, 2003.
2. Gomes, T.A.T.; Rassi, V.; MacDonald, K.L.; Ramos, S.R.T.S.; Trabulsi, L.R.; Vieira, M.A.M.; Guth, B.E.C.; Candeias, J.A.N.; Ivey, C.; Toledo, M.R.F.; Blake, P.A. Enteropathogens associated with acute diarrheal disease in urbans infants in São Paulo. J. Infect. Dis., 164:331-337, 1991.

3. Köhler, G.; Milstein, C. Continuous cultures of fused cells secreting antibody of predefined specificity. Nature, 256:495-497, 1975.

4. McKinney, M.M.; Parkinson, A. A simple, non-chromatographic procedure to purify immunoglobulins from serum and ascites fluid. J. Immunol. Methods, 96:271-278, 1987.

5. Nataro, J.P.; Kaper, J.B. Diarrheagenic Escherichia coli. Clin. Microbiol. Rev., 11:142-201, 1998.

6. Reis, M.H.L.; Guth, B.E.C.; Gomes, T.A.T.; Murachovschi, J.; Trabulsi, L.R. Frequency of Escherichia coli strains producing heatlabile toxin and heat-stable toxin or both in children with and without diarrhea in São Paulo. J. Clin. Microbiol., 15:1062-1064, 1982.

7. Souza, E.C.; Martinez, M.B.; Taddei, C.R.; Mukai, L.; Gilio, A.E.; Racz, M.L.; Silva, L.; Ejzenberg, B.; Okay, Y. Perfil etiológico das diarréias agudas de crianças atendidas em São Paulo. J. Pediatr., 78(1):31-38, 2002.

8. Svennerholm, A.M.; Holmgren, J. Identification of Escherichia coli heat-labile enterotoxin by means of a ganglioiside immunosorbent assay (GM1-ELISA). Current Microbiol., 1:19-23, 1978. 